\title{
Dilemmas of Diaspora: Partition, Refugees, and the Politics of "Home"
}

\author{
Pablo Bose
}

\begin{abstract}
The following paper explores the idea of "refugee diasporas" by focusing on a case study of the Hindu Bengali exodus from East Pakistan (later Bangladesh) following the 1947 British Partition of India. The author begins by problematizing and historicizing definitions of diasporas in general and refugee diasporas in particular and then uses the case study to illustrate the diversity in experiences that different groups that emerged from the Partition encountered. This focus on the lived experiences of flight, resettlement, integration (or lack thereof), and the rebuilding of lives helps to unravel some of the embedded and obscured meanings that terms such as "refugee diaspora" might otherwise contain.
\end{abstract}

\section{Résumé}

L'article explore la notion de "diasporas de réfugiés " qu'il illustre par l'exode d'hindous vers le Bengale depuis l'est du Pakistan (qui deviendra le Bangladesh), à la suite de la partition britannique des Indes de 1947. L'auteur commence par poser la problématique et l'historicité des définitions se rapportant aux diasporas en général et aux diasporas de réfugiés en particulier. Il se sert ensuite du cas cité pour mettre en lumière la variété d'expériences auxquelles ont été soumis les divers groupes issus de la partition. Cette focalisation sur des expériences vécues de déplacement, de réétablissement et d'intégration (ou de leur absence), de même que de reconstruction de vies permet de dénouer quelques-unes des significations implicites ou moins évidentes que des expressions comme " diaspora de réfugiés " pourraient autrement connoter.
$\mathrm{D}$ iasporas have become increasing objects of study and attention in recent years. Diasporic communities may take many forms and engage in a substantial range of activities, yet "the diaspora" continues to resonate for scholars, social movements, and national governments (amongst others) as a locus for examining transnational practices, particularly in terms of global capital and political and cultural flows. What do diasporas and their activities tell us about identity, citizenship, community —indeed, what do they tell us about the nation-state itself? How are our notions of borders and boundaries disrupted by groups whose idea of a "homeland" does not fit easily onto a map or a census? This paper seeks to explore such questions by critically interrogating the idea of the "refugee diaspora." I begin by examining the construction of "diasporas" as a broad category of migration-forced and otherwise-throughout history. I look specifically at the tensions of nationality, identity, and the connection to place which are, in particular, markers of the "refugee diasporic" experience. I explore these issues by focusing on a specific historical event - the British Partition of India in 1947-and the diverse set of East Bengali refugee diasporas that emerge out of this period. This case highlights some of the complexities in identifying diasporic groups (including refugee diasporas) as unified or monolithic communities and instead shows some of the distinctions that class, caste, gender, ethnicity, and religion play in constructing their narratives, experiences, and imaginations. The final section of the paper looks at the legacies of the Partition and East Bengali refugees and the ongoing contestation over "home," as these are played out in within India and throughout the global Bengali diaspora.

\section{Defining and Distinguishing Diasporas}

Diasporic communities have existed for centuries and in many ways complicate modern notions of geographic and political boundaries. They are multi-faceted social organi- 
zations, interwoven in the contemporary context with legacies of colonialism and emerging trends towards cultural, economic, political, and social globalization. Diasporas take many forms beyond the traditional notion of persecuted victims forced to flee their homeland, though the enduring image of diasporic communities remains bound not to the notion of migration, but rather to that of forced displacement. It is the so-called "victim diasporas"1 that dominate our view, such as Jewish groups persecuted across Europe through the centuries, Africans scattered by slavery over the Americas and the Caribbean, or, more recently, Armenians and Palestinians, displaced by genocide or deprived of a homeland.

But in recent years many other groups have increasingly been described by the category of diaspora. Alternative labels are often used synonymously-transmigrants, émigrés, immigrants, and expatriates among them-though these terms describe sometimes very different forms of population movements. Regardless of the reasons for "leaving," it is nonetheless true that generations of communities have flourished away from their "original homelands," retaining strong economic and political ties to their places of origin and often a distinct cultural identity. Scholars have documented many such cases throughout history, and point to similar examples in the contemporary context. These include trading communities such as Lebanese, Chinese, Italian groups who migrated to distant shores, labourers (indentured or otherwise) from various parts of the Indian subcontinent who journeyed to Africa, the Caribbean, and Southeast Asia, and functionaries and soldiers from ancient Rome and colonial Britain, Russia, France and Belgium who spread throughout their empires. More recently, the postcolonial period has seen massive migration from former peripheries towards self-described cores-East and West Indians in Britain, North Africans and Southeast Asians in France, Central Asians in Russia, to name but a few. And indeed migrant labour across the world today represents one of the most significant flows of population in human history, from South Asians in the Persian Gulf to Latin Americans in the United States, and Eastern Europeans in Western Europe and many others besides. ${ }^{2}$ The latter example does not simply mean seasonal workers who return to their "home" countries following the expiration of a contract or the harvest of a crop (though it might in some instances). Increasingly, whether arriving as legal or undocumented labour, such migrant workers have stayed on in host countries, settling in discrete, identifiable communities, and sending financial support to their families left behind. ${ }^{3}$ It is indeed this dialectic, of connections to both a "new" and an "old" home simultaneously, that is characteristic of diasporas, no matter what their origin.
Given this wide range of definitions, however, one might well ask whether the category of diaspora continues to be a useful one to describe specific communities of refugees or whether it is too large and unwieldy as either a descriptive label or analytical framework. Some scholars disagree with including so many forms of population movement under the umbrella of diaspora and argue instead that only cases of forced migration should qualify. Others limit the term only to its capitalized use, that of the Jewish Diaspora, while yet others extend this narrower definition to include the descendents of African slaves and more contemporary victims of genocide rebuilding shattered lives elsewhere. ${ }^{4}$ From such perspectives, the role of compulsion is central in identifying whether a community is diasporic or migrant in nature. Individuals and communities must have been forced to shift from one place to another in order to have been displaced. A further implicit connotation is that the actual compulsion itself is at the behest of a human agent. The motivations behind forced migration, in this view, are often part of a larger political strategy, tribal animus, or base self-interest.

But there are many problems with such a rigid reading of population movement, even of a forced nature. It is relatively straightforward to identify certain instances of forced migration-being kidnapped and sold into slavery, fleeing homes and livelihoods in the face of a violent and oppressive state or army or mob, for example. But there are many other and more subtle forms of pressure that have compelled population movements throughout history. The threat-rather than the actual experience-of violence has been a powerful motivator for flight. As well, one could argue that the economic motives which have driven many groups to relocate have themselves constituted a strongly coercive process-for example, Irish, southern Italian, and eastern European immigration to North America in the nineteenth and early twentieth centuries or Indian travels to the Caribbean and Africa during the same period-though many of these migrants in strictly technical terms "chose" to leave their homes for a new life and were not forcibly transported as a result of conflict, slavery, or some other unwanted compulsion. Yet many cases such as those mentioned above arise as a result of specific economic policies and development initiatives of colonial powers and emerging nation-states.

Similarly important for some groups has been a potential loss of social standing and power rather than an overt threat of violence, as this paper will later note in the case of some East Bengali refugees. There are also those refugees who flee from events that have no direct evidence of human intervention-certain environmental disasters or climatic changes, for example. Other cases show human agency but 
neither overt malice or forethought nor enough consideration and planning for the refugee crisis that has been created. Development-induced displacement, for example, is an acute crisis in the contemporary context, with close to 100 million people across the globe now forced out of their homes and homelands for the purposes of economic development. ${ }^{5}$ Such geographic displacement can be within a city or district, from one village or neighbourhood to another; it can also involve displacement across long distances and borders, sometimes to economically, socially, and culturally quite different settings. Development that displaces therefore has created masses of the so-called "internally displaced"- those dislocated not necessarily across national borders but within them. Some of these refugees have had little say in the decisions that led to their former homes being swallowed whole by the reservoirs of dams or the asphalt of highways. Some have been offered varying levels of compensation for their loss-sometimes money, sometimes land, though rarely enough or of the same quality they previously enjoyed. Most have not chosen to be displaced; rather, it is a reality that has been forced upon them, and they are left sundered from homes and occupations as a result. They are refugees in fact, if not always in law, since the development-induced displaced are often refugees not across borders but within them. They are the "internally displaced," those millions of refugees who fall outside the 1951 UN Convention on the Status of Refugees definition restricted to an individual "outside the country of his nationality." 6

\section{Diasporas, Home, and the Nation-State}

Such complexities remind us that it is important not to confuse the exiles' longing for "home" and "place" with some kind of inherent connection to the nation-state. Diasporas certainly predate the modern post-Treaty of Westphalia notion of the nation-state and so too do the "victim" or "refugee diasporas," as the historical record clearly demonstrates. There is nothing to suggest that the attachment to place arises from a flight across lines on a map or displacement from one's nationality. But in an era where the nationstate is seen by many as the ultimate expression of community and its existence appears inevitable (though somewhat altered by globalization), it seems only logical that forced displacement from the nation would be the point at which refugees are created. Indeed, as Benedict Anderson has argued, the very success of the idea of the nation-state has been in (1) harnessing the latent power of "nationalist" sentiments within the political framework of the state, and (2) thereafter exercising control over geography, history, demography, and the legitimate use of coercive force in the name of that nationalist sentiment. ${ }^{7}$ The "map, the census and the museum," Anderson suggests, have been amongst the most effective tools in regulating geographical boundaries, population movements, and cultural memories within a world system of nation-states.

But diasporas - and especially refugee diasporas-disrupt this tidy view of nation, narration, and belonging. Refugee diasporas may indeed be a group of people forced by conflict or persecution to flee lands and homes to which they have long-standing political, economic, and cultural ties-but it is more often "homes" that are left behind, rather than "nations." As a community in exile, "refugee diasporas" are often defined by their nationality-Somalis, Afghans, Iranians-yet are their connections to "home" predicated on the nation? Certainly within the larger diasporic population, the link is not so clear. Try as many national governments might, attempts to raise funds for various nation-building projects in putative homelands have been far less successful than the efforts of "hometown associations" or the more common informal transfers of funds between family members and friends. ${ }^{8}$ The ties that bind are more often to place than they are to the grand notions of an imagined community in the form of the nation-state. The exile that the refugee communities experience is from their homes and the lives that they are forced to try and reconstruct might be built as much in another part of their country of origin as in a distant land-though both might be equally foreign to them. The displaced from development projects from central India often end up living in cities on the coasts, for example, in discrete, if often wretched communities. In other cases, populations fleeing conflict and violence cross an international border to become refugees in neighbouring countries whose populations might be quite similar in cultural practices and beliefs to them and whose "difference" has less to do with nationalism and more with the arbitrary boundaries of competing colonial powers (as in the case of many African countries).

All of this is not to say that the nation does not matter. Indeed, for many refugee diasporas who do not come from a nation-state with which they identify the dream instead is of a country of their own, such as elements of the Sikh, Kurdish, and Sri Lankan Tamil diasporas have suggested. Still, the claim to "place" and "home" is based primarily on what Soumitra De calls the "territorial referent," rather than on the necessity of the nation-state:

[While] the statehood demand is not a must for nationalism, a territorial referent is. Nationalism proceeds to define people in terms of shared institutions, economic, social and/or political (such as language, religion, customs, etc.) and defends or seeks to increase their autonomy. All the while this demand for autonomy is made in terms of belonging to a particular terri- 
tory. Often, to make this demand compatible with the territorial referent, nationalists mystify the connections by referring to a remote past (usually heroic) and/or to a better future. Thus, while a nationalist ideology is conditioned by its location in an actual space and time, it is also a unique and creative time-space formulation. Quite naturally, therefore, nationalism can be used by different social groups and classes for different and often conflicting purposes. ${ }^{9}$

It is in the light of these complex and contested claims to both nationalism and what might be termed "sub-nationalism," therefore, that the idea of the refugee diaspora must be evaluated, paying particular attention to the different reasons for departure, the diverse ongoing connections to "homelands" (real or imagined), and the differences in experiences of the vast numbers of refugee diasporas. Many of these groups, for example, have developed vibrant, established, "successful" diasporic communities in their countries of refuge; others remain marginalized, often continuing to live for decades in camps under less than ideal conditions and denied the rights and privileges enjoyed by their immediate neighbours. Examining the diverse and complex experiences of resettlement, integration, and ongoing relationships with putative homelands is a key component in understanding the makeup and mentality of refugee diasporas. A focus on these differences is also an important part of not treating these groups as monolithic entities but rather as varied as any other community. The next section will examine such differences by focusing on the case of the Partition of Bengal.

\section{The Partition of India and the Creation of the East Bengali Diasporas}

The division of the Indian subcontinent by the British in 1947 at the moment of their departure signified a simultaneously momentous and calamitous event. The creation of a majority Hindu India and a bifurcated, mainly Muslim Pakistan (with eastern and western wings) was predicated on the colonial notion of two indigenous populations locked in eternal enmity and strife. The Partition, as the event became known, was portrayed as a compromise solution aimed at appeasing both sides and imposing order on a chaotic situation. Instead, the redrawing of the map unleashed a torrent of bloodshed and violence scarcely seen before or since. Nearly one million died in so-called "communal" violence between Hindus and Sikhs on the one side and Muslims on the other. An estimated fifteen million people were displaced with close to two million killed. The population movement itself is one of the largest in recorded human history and the echoes of the Partition remain writ large on the psyche and character of all three nations (India,
Pakistan, and Bangladesh) that eventually emerged out of its ashes. It has become, as one writer describes it, a "topic of much myth-making, intense polemics, and considerable serious historical research." 10 The Bengali-American novelist Jhumpa Lahiri describes her father's explanation of Partition and the suddenly discovered differences between East and West Bengalis in the following manner:

“Mr. Pirzada won't be coming today. More importantly, Mr. Pirzada is no longer considered Indian," my father announced, brushing salt from the cashews out of his trim black beard. "Not since Partition. Our country was divided. 1947.” When I said I thought that was the date of India's independence from Britain, my father said, "That too. One moment we were free and then we were sliced up," he explained, drawing an X with his finger on the countertop, "like a pie. Hindus here, Muslims there. Dacca no longer belongs to us." He told me that during Partition Hindus and Muslims had set fire to each other's homes. For many, the idea of eating in the other's company was unthinkable. It made no sense to me. Mr. Pirzada and my parents spoke the same language, laughed at the same jokes, looked more or less the same. They ate pickled mangoes with their meals, ate rice every night for supper with their hands. Like my parents, Mr. Pirzada took off his shoes before entering a room, chewed fennel seeds after meals as a digestive, drank no alcohol, for dessert dipped austere biscuits into successive cups of tea. Nevertheless my father insisted that I understand the difference, and he led me to a map of the world taped to the wall over his desk. He seemed concerned that Mr. Pirzada might take offense if I accidentally referred to him as an Indian, though I could not really imagine Mr. Pirzada being offended by much of anything. "Mr. Pirzada is a Bengali, but he is a Muslim," my father informed me. "Therefore he lives in East Pakistan, not India." 11

However, it is important when examining the experiences of one particular group of refugees that resulted from this event to distinguish between the myth of the Partition (as it has grown in the half century since it occurred) and the actual event itself. It is important, for example, to note that the British notion of an irresolvable Hindu-Muslim dichotomy in India is deeply flawed and says more about the colonialist mindset and insecurity than about the restless subjects of the Raj themselves. ${ }^{12}$ To begin with, the notion of two unified, monolithic communities of Hindu and Muslim co-religionists is profoundly inaccurate and does a great disservice to the cultural, linguistic, ethnic, and indeed religious differences that characterize the many adherents of these groups within the vast Indian subcontinent. This view also fails to recognize all those other communities within the Indian social fabric, from Jains and Sikhs to millions of tribal groups and many others. Finally, 
the presumptive position of the British Raj as arbiter between warring groups is belied by its own role and responsibility in fostering local enmities and nationwide grievances, as part of a colonial strategy of "divide and rule." 13

But it is not only the British colonial view of the hardpressed, benevolent shepherd guiding the fractious natives towards freedom that needs to be challenged in problematizing the myth of the Partition. The story within the subcontinent itself has become highly charged, in the first instance by the effects of the tragic violence and destruction of the post-Independence period, and by fifty years of on-and-off tensions and conflicts, several wars, and decades of political posturing. For nationalist elites in both India and Pakistan — both of whom, as Ranajit Guha has argued, were actively working to substitute the hegemonic power of the British with that of their own ${ }^{14}$ - the story of Partition was one of an anti-colonial struggle whose success was betrayed in part by the greed and desire for control of their one-time partners in the drive to rid the subcontinent of the British. The Pakistani mythology is shaped by the belief that Muslims would always remain an oppressed minority within an India ruled by Hindus. The Indian mythology, on the other hand views Partition as the inevitable outcome of the scheming and ever-increasing demands of the Muslim leadership on the dreamt-for nation-state. But many of the Subaltern Studies school of historians have called into question such views. Gyanendra Pandey suggests that:

[the] historians' history of Partition has, in India, been a history of crisis for the Indian nation and the nationalist leadership. It has been a history of the machinations which lay behind this event, and the lessons to be drawn by the nation for the future. This is not a history of the lives and experiences of the people who lived through that time, of the way in which the events of the 1940s were constructed in their minds, of the identities or uncertainties that Partition created or reinforced. Even as a history of crisis for the Indian nation, therefore, this history is inadequate. $^{15}$

The inadequacy of the mythologized views of Partition is an impediment to both our historical understanding and to the continued challenges of politics and life in the subcontinent today. Religious groups in India and Pakistan continue to draw on the Partition and its symbols as powerful markers for their arguments today. The incident that set off the horrific pogroms against Muslims in the state of Gujarat, India, in 2002, for example, was the burning of a train filled with Hindu worshippers. This act had a tremendous cultural resonance in parts of northern and western India, where memories of trainloads of dead arriving across the borders of both Pakistan and India after Partition resurfaced. ${ }^{16}$ The Hindu right in India, as part of its program of revising its own history and recasting its own collaborationist past, has increasingly shifted responsibility for the Partition away from Hindus, Sikhs, and even the British and explicitly and vocally blamed the Muslims. Recent publications from adherents of the Hindu right in India have gone so far as to call the experiences of the Hindus a "holocaust" and compared the lives of Hindus in Pakistan and Bangladesh to those lived in a concentration camp. ${ }^{17}$ Such rhetoric obscures the very "history of the lives and experiences of the people who lived through that time" that Pandey calls our attention to. As William van Schendel notes, the Partition is best understood not only in terms of nationalist and anti-colonial politics (and ongoing antagonisms), but also "as a cultural and personal disaster, the fissure of two major regional cultures (Punjab and Bengal) which were divided between the successor states, and the personal suffering and traumatic memories of millions of uprooted refugees." 18

\section{Differences in Partition Experiences}

Indeed, the experience of Partition itself was markedly different in the two regions. Northern India, in which the province of Punjab was divided and one half joined Baluchistan, Sind, and the North-West Frontier Provinces to form West Pakistan, witnessed a tremendous and violent upheaval over a roughly three-year period (1947-1950), characterized mainly by a population exchange between Hindus and Sikhs coming to India and Muslims arriving in Pakistan. This exchange was anything but orderly; however, it did involve significant government intervention and resettlement and rehabilitation efforts, with refugee populations often occupying the homes and businesses of their departing counterparts. A new capital city of Chandigarh was built for the Indian province of Punjab while the national capital New Delhi absorbed so many newcomers that it has been described by some as a "city of refugees," particularly of a Punjabi refugee diaspora. ${ }^{19}$

In Eastern India, the Partition was similarly violent, but occurred as part of a much more gradual, ongoing and cyclical process, and with far less population exchange or governmental intervention. The region being divided consisted mainly of the province of Bengal, along with some Muslim districts of neighbouring Assam. Interestingly, this was not the first British Partition of Bengal, a once vast province that had been progressively whittled down through the late nineteenth and early twentieth centuries under the guise of administrative reform. In 1905 the British had divided the province into Hindu and Muslim halves, a move bitterly contested by Hindus in particular, who had more to lose in terms of power and influence. By 
1911 the British had rescinded the order and rejoined the two halves. But this earlier Partition of Bengal remained a pivotal memory for many Bengalis, especially those who had been involved in the nascent nationalist struggle and who felt the British action was punishment for their politicization. $^{20}$

In 1947, when the second and permanent Partition occurred, opposition to the move was much more muted. Many Indian Bengalis continue to blame separatist sentiments amongst the Muslim leadership for the Partition of Bengal, yet as Joya Chatterji and others have argued, Hindu communalists were vociferous in their demands for an autonomous, Hindu-dominated region of Bengal. ${ }^{21}$ And indeed, the population flow was overwhelmingly from east to west, by Hindus towards India. The exodus in fact preceded the actual Partition, beginning with the departure in 1946 of Hindus following riots in the districts of Noakhali and Tippera in East Bengal. Over the next fifteen years, a steady stream of people moved from East Pakistan to West Bengal, some 5.28 million individuals between 1946 and 1970.22 The causes for this continuous flow were numerous-the 1947 Partition and its aftermath, episodic riots within East Pakistan (especially in the districts of Barisal and Khulna), depressed economic conditions within the region, the introduction of passports by India and Pakistan to regulate travel (intended to stem the tide of migrants, but in fact resulting in the opposite due to insecurities this attempt caused), and conflicts within India and Pakistan itself, whose impact reverberated within both halves of the former Bengal and led to violence in each. ${ }^{23}$ In 1971 an even greater number of refugees emerged due to a new crisis: the brutal repression of Bangladeshi nationalists (both Muslim and Hindu) by the West Pakistani army. Some estimates suggest that as many as three million people were killed and an additional twelve million fled as refugees to India. ${ }^{24}$

The Partition, then, was a very different phenomenon in northwestern and eastern India. Refugees in the northwest, some critics argue, were the prime beneficiaries of government aid and attention from the new Indian state. Prafulla Chakrabarty contends that this northwest-centric preoccupation in the post-Independence period stems from the placement of the power centres of the new Pakistan and India in the north and west (and their proximity to each other), rather than the east. ${ }^{25}$ In the decades that have followed, academic inquiry, popular literature, and cultural representations have similarly focused mainly on Partition narratives from the north. ${ }^{26}$ But those scholars who have looked at the division of Bengal as a counterpoint to that of Punjab have looked at the differential treatment of refugees not only within the subcontinent, but within the separate regions themselves. This is to say that disparities exist not only between the treatment of northwestern and eastern subjects of partition as Chakrabarty suggests, but within and amongst the East Bengali (as doubtless with Punjabi) refugees themselves.

Such disparities become abundantly clear if one looks at the caste and class composition of East Bengali refugees and at their resettlement experience in Calcutta, the primary destination for most migrants. The earliest refugees, those who came in the years 1946-1948, were mainly East Bengali bhadralok. This is a category that describes a group who have been variously described as a "westernised caste elite," 27 the "dominant upper crust of Bengali society who enjoyed a despotism of caste tempered by matriculation," 28 and a group of urban, professionalized, middle-class landowners. The term literally means "good-mannered people," and the self-proclaimed connotation is of "respectability," "education," and "proper rearing," It is not easy to define the bhadralok through western categories since they are usually-though not exclusively-upper caste, distinguished by education and non-manual labour, but unlike the middle class of western industrialized nations, the bhadralok derived their power not from trade or industry, but rather from land. ${ }^{29}$ It was their position as the rentier aristocracy of the British colonial system-the zamindari-that secured for the bhadralok their access to capital, education, professional opportunities, and the attendant benefits of a "refined" lifestyle. ${ }^{30}$ Refugees who arrived in later periods, particularly from 1950 onwards, were from a different segment of East Bengali society, mainly peasants, agricultural and manual labourers, and industrial workers, most from lower caste backgrounds. Nilanjana Chatterjee has suggested that whereas the majority of these later refugees fled from violence, many of the earlier bhadralok refugees left because of a combined fear of physical harm, a downturn in economic opportunities, and a perceived loss of social standing and power. ${ }^{31}$

\section{Resettlement and Migration of the East Bengali Refugee Diasporas}

While some of these various groups of refugees settled in relatively contiguous areas (i.e. refugees who lived near border districts moved across the border into both the eastern and northern parts of West Bengal), the vast majority - some 70 per cent of those from East Pakistan-travelled to Kolkata. ${ }^{32}$ This was particularly true for those fleeing the central and western districts of East Pakistan, who therefore had in many ways the most alienating resettlement experience to contend with. For the early bhadralok arrivals in Kolkata, the time is one of considerable hardship and transition, but the process is by and large one of integration into Kolkata society. Many had no desire to be classified as 
refugees, with the social stigma attached to that status, and certainly they had no desire to settle in the government-run refugee camps. Rather, the bhadralok built on existing social networks and contacts with friends and family to help them resettle and integrate into the economic and political life of the region. ${ }^{33}$ In some cases, bhadralok families already had established residences in both eastern and western Bengal-a city and a country home, or an industry in Kolkata and a landed estate in East Bengal—and their transition was made easier. For others, the move to Kolkata meant moving from luxury to (relative) privation, living in cramped quarters, rebuilding lives under difficult circumstances.

For the lower class and caste refugees from East Pakistan, those who came from 1950 onwards, the experience was considerably different. They did not have access to the social networks of the bhadralok who preceded them. Most of the lower class and caste refugees had also been displaced from industrial occupations and agricultural or fisheriesbased livelihoods. While the influx of many new bhadralok into Kolkata had caused some degree of labour market displacement within the urban economy, this impact was minimal and confined primarily to the professional sector. For the lower caste and class refugees, there were many fewer jobs to compete for. In many cases, these later refugees were in fact sundered by a new border from work itself, as the Partition drew an artificial line between lives and livelihoods where one might find all of a sudden that one's work was now located in another country. ${ }^{34}$

Additionally, many Partition refugees from this period had difficulty in even being recognized as such, a problem that was to be repeated in the coming decades. Those who were classified as refugees were given identity cards and placed in one of two types of housing, refugee colonies or refugee camps. Those in the former received some level of resettlement and rehabilitation assistance, while those in the latter were granted less. ${ }^{35}$ But the definition of refugee status itself was becoming quickly and hotly contested in Bengal, further affecting the treatment of those fleeing East Pakistan. In the aftermath of Partition, the Government of India had defined refugees in the following way:

A displaced person is one who had entered India (who left or who was compelled to leave his home in East Pakistan on or after October 15, 1947) for disturbances or fear of such disturbances or on account of setting up of the two dominions of India and Pakistan." 36

But by the 1970s, the terms "refugee" and "displaced" had increasingly been replaced in official language by "migrants." Indeed, the Government of West Bengal today draws a clear distinction between "new" and "old" migrants:

(a) Those who migrated between October 1946 and 31 March 1958 are known as old 'migrants'

(b) Those who came between 1 January 1964 and 25 March 1971 are known as 'new migrants' ${ }^{37}$

Such definitions reflect the growing distrust and suspicion with which the central Indian government, the state authorities in West Bengal, and a sizable section of middleclass and elite Bengali society viewed the ongoing population flow from East Pakistan. If the early years of Partition had elicited sympathy for the horrors that the survivors of violence were fleeing, by the 1960s many policy makers and politicians wondered aloud whether refugees were in fact fleeing violence or merely leaving a stagnant local economy for brighter prospects in the western half of the former Bengal. ${ }^{38}$ It is undeniable that the massive and ongoing influx of refugees was a tremendous drain on social services and had a considerable impact on the political and economic structure of both the state of West Bengal and the city of Kolkata. Kolkata in particular has long suffered from a reputation as a disordered and chaotic metropolis, yet it is hard to imagine any urban space increasing by a third in population over such a short span of time and still maintaining itself without difficulties.

\section{Double Displacements: Forced Relocations of East Bengali Refugees}

Despite these obvious problems, the treatment that many refugees from East Pakistan received at the hands of the state and central governments in India during the 1950s and 1960s is hard to justify. This ranged from denying them adequate aid, resources, and opportunities to outlawing some of their settlements to outright forcible relocations. This last included transporting large numbers of East Bengali refugees to distant regions of India such as the Andamar and Nicobar Islands, Bettiah in Bihar, and the Dandakaranya district of Madhya Pradesh. ${ }^{39}$ The last is a particularly notorious case, with tens of thousands of peasants from the former East Bengal resettled in a hill-area. There was a dual purpose to this project: rehabilitation of the East Bengal refugees and the "civilization" of a local tribal group through enforced contact with the newcomers. This (as with many of the other experiments) was by most accounts an abject failure, with conflicts arising between tribals and refugees and the inability of many of these Bengalis from agricultural backgrounds to adjust to cultivation in a very different environment and resource base. ${ }^{40}$

The East Bengali refugees did not, of course, accept this situation meekly. Transportation to Dandakaranya and other distant places was vocally opposed by the refugee 
populations. Indeed, several thousand refugees even returned to Bengal from Dandakaranya, occupying an uninhabited island for some time before being again forcibly evicted by the government. ${ }^{41}$ And as early as 1949 , refugee activists had mobilized their communities in order to provide shelter and livelihoods for themselves, rather than relying on aid from various levels of government. One of the most visible signs of this mobilization was in the development of the squatters' colonies on the edges of Kolkata, known as jabar dakhal. ${ }^{42}$ These were large areas of vacant land, owned either privately by landlords or by the government. In some cases parcels of land were purchased legally; in others, a process of collective takeover simply established the refugee presence as a community on the ground. They were inhabited mainly by middle-class and working-class refugees from East Pakistan, those who eschewed (and had the means to avoid) living in the government-run refugee camps. By 1950 there were close to 150 refugee colonies, concentrated mainly around the southeastern portion of Kolkata and often butting right up against the mansions of the wealthy. These locations gave residents in the refugee colonies access to a range of possible livelihoods including aquaculture, farming, and work in the industrial sector. ${ }^{43}$

Such initiative was, however, looked upon with considerable suspicion by the central government, which attempted to regulate the conversion of both public and private lands into more permanent dwellings for refugees by passing the Eviction of Persons in Unauthorised Occupation Land Bill in 1951. Refugees in both camps and colonies mobilized against this, as they would later against forcible transportation, by forming collective organizations and committees, such as the umbrella organization, the United Central Refugee Council (UCRC), and by launching non-violent political agitations. ${ }^{44}$ The political activities of the refugees met with varying levels of success and resistance over the years, but the camps and colonies proved a fertile base of support for at least one regional political party. The Communist Party of India-Marxist (CPIM), which would go on to rule West Bengal from 1977 onwards, was one of the first political organizations to pay explicit attention to the demands of the refugees and thereby won their early support.

Yet despite these hard-fought struggles to recognize their plight, the refugees from East Bengal have not disappeared from the landscape of Kolkata. Unlike many of those who arrived in the early years before, during, and just after Partition, the later refugees (or "migrants" as the government calls them) have not become assimilated into a broader Kolkatan or West Bengali society. Even today, some 931 refugee colonies and camps are recognized by the Kolkata Metropolitan Development Authority; scholars claim that a further 998 exist without official sanction. ${ }^{45}$ And unlike the South Kolkata colonies that eventually became respectable middle-class neighborhoods of the bhadralok, the refugee camps and colonies in the north, east, and west of the city remain identifiable as such, similar in form to the hundreds of slums (or bustis) that dot the metropolitan region.

Both of these particular manifestations of the East Bengali refugee diaspora-the one represented by the bhadralok of Kolkata and their international brethren, and the one that lives in the slums and camps on the edges of the city-are locked today in an ongoing struggle over a region to which they (as well as others) have both a cultural and an historical claim. This contest over home, place, and memory is being played out particularly noticeably in the development of housing projects on the southern and eastern fringes of the city. It is in these areas that the Kolkata Metropolitan Development Authority has plans for refugee colony development projects (along the lines of the ubiquitous "slum improvement" initiatives undertaken across India) in three phases which will involve 174, 324, and 88 colonies, respectively. ${ }^{46}$ But these are also the same regions that have seen an enormous increase over the past ten years in new western-style housing projects and their requisite attendant facilities (shopping malls, country clubs, and entertainment complexes). The construction continues at a furious pace, in areas that are ecologically sensitive, provide a majority of the foodstuffs for urban markets in Kolkata, and are both home and livelihood to many of the East Bengali refugees. But many of these homes and refugee colonies are, as noted earlier, the result of illegal occupation of land. And despite the fact that some residents have lived in these regions for decades-many since Partition itself - with established livelihoods and social networks, tens of thousands find themselves once again facing the prospect of displacement.

Ironically, the market towards which the new housing projects are aimed is primarily the international Bengali diaspora which has, as noted previously, deep roots in the Partition experience itself. Interviews with developers and promoters of these housing complexes indicate that between 25 per cent and 75 per cent of apartment ownership is by overseas Indians-both the so-called "non-resident Indians" (NRIs) and "persons of Indian Origin" (PIOs). ${ }^{47}$ Promotional Web sites and advertisements explicitly target diasporic groups - or those who wish to live like them. A highly visible advertising campaign on billboards throughout Kolkata for the South City Projects promises would-be buyers that they can "live the way the world does." Other complexes offer "western-style amenities" and send travelling sales caravans to diasporas in London, New Jersey, and 
Toronto. Shopping malls in Kolkata's peri-urban fringes are similarly constructed with assumed diasporic sensibilities and pocketbooks in mind. The best and brightest in multinational brands are represented amongst the retailers and the malls replicate the "big box" concept so prevalent in suburban North America. It is the life of the wealthy, middle-class North American in particular, idealized in the figure of the successful NRI who has "made it" as an IT, medical, engineering, business, academic, or legal professional, that is being sold here, paradoxically both to Indians and NRIs/PIOs alike. In the case of the diasporic Indians, seeing themselves represented as success stories through Bollywood cinema, Indian television and song, as well as in various governments' new attraction to their capital, serves to reinforce this particular image of what it means to be a member of the diaspora.

One member of a local social movement in Kolkata that has challenged displacement due to urban development recently asked, as we walked by a project of 36-storey apartment buildings set amidst golf courses, swimming pools, country clubs and other gated communities, "Why do overseas Bengalis feel that they need to live in the wind?" 48 The phrase "living in the wind" is a play on another local advertising campaign which tells apartment buyers that they can "live in the sky" in a 36-storey building (constructed on recently filled alluvial soil). It also denotes a sense of transience attributed to some members of the diaspora and their attachment to a local place, at least in the estimation of people like the speaker. To those like him, the new development complexes are clearly aimed at diasporic groups and their assumed needs and desires, a set of preferences that is removed at several levels from those of "ordinary" Bengalis, set above and apart and ephemeral all at once. Yet for many other Indians within India-particularly in the emerging and enlarging middle classes-the NRI and the lifestyle associated with them has equally become an object of aspiration. This segment of the Bengali refugee diaspora, in this sense, is sustaining and transforming a somewhat idealized homeland-at the same time that they are themselves sustained and transformed by events and perceptions within their homeland. But should their ongoing attachment to "home" supersede the claims and lives of another group who are themselves seriously affected by these developments?

\section{Conclusion}

Is it possible, in light of the case described above, to identify a single, unified East Bengali refugee diaspora, with a shared set of experiences and memories of displacement? If anything, the evidence would indicate the opposite, that indeed the Partition of Bengal and the gradual process of displace- ment that followed resulted in the creation of multiple refugee diasporas, including ones that settled in various parts of West Bengal, notably Kolkata, and ones that traveled as part of a postcolonial globalization process to areas such as North America and Europe. The latter are not refugee diasporas in many commonsense understandings of the term, not fleeing from violence, not settling in exile in a foreign land, not even removed unwillingly to a different part of their own country. Yet I would argue that an integral component of the cultural fabric for much of the international Indian-Bengali diaspora is in fact the experience of Partition. This stems in part from the fact that much of this diaspora is composed culturally and socially in large part by the bhadralok.

Unlike the Sikh, Gujarati, Marathi, or South Indian groups-part of a global Indian diaspora that is some 20 million strong - who emigrated in earlier periods as wagelabourers, traders, and workers in agriculture, forestry, and the service sector, Bengalis from India have emigrated overwhelmingly as professionals. Most have emigrated as highly trained doctors, lawyers, engineers, and academics. In diasporic settings from New Jersey to London to Toronto, their children often follow in their footsteps, echoing the century-old bhadralok preoccupation with scholastics, learning, and upward mobility. For these prabasi (overseas) Bengalis in particular, select memories of the Partition dominate their imaginary images of East Bengal as a land of rivers and fields and countryside; indeed, recalling the very real political, economic, and social importance of land itself in their existence. As a child growing up in the Bengali diaspora in Canada, such narratives are familiar to me-the tales of a land left long behind, the unspeakable violence experienced, the years following Partition spent in deprivation and misery, families huddled together in tiny rooms, the indelible scars of the past etched into our present. Even today, friends of my generation in the Bengali diaspora talk of their parents' unwillingness to sell their homes and say, "Well, a house is so important to them, you know, because they lived through the Partition. ..."

Yet what such monolithic narratives of the Partition obscure are the diverse, complex, multi-faceted, and gradual processes that in fact characterize the displacement and diasporic journeys of East Bengali Hindus. The discourse of a singular Partition experience that was uniform in its tragedies, its effects, and its outcomes belies the ongoing existence of a refugee diaspora within Kolkata itself. These are those millions who still live in refugee camps and colonies, many of them little more than slums, who have formed discrete communities, workers' collectives, hawkers' associations, and myriad other social and political organizations that assert their identities as apart from that of the 
broader West Bengali population. They call themselves the bastuharas or udbastus; literally, "homeless" or more evocatively "home-land-less". ${ }^{49}$ Their experiences contradict many of the myths that continue to prevail within both West Bengal and the international Bengali diaspora regarding the Partition of 1947. It is in focusing on the experiences of the various diasporas produced by events such as the Partition that the importance of the category of "refugee diaspora" itself is understood in terms of forced migration and identity in an age of globalization.

\section{Notes}

1. Robin Cohen, Global Diasporas (London: UCL Press, 1997).

2. Jana Evans Braziel and Anita Mannur, eds., Theorizing Diaspora: A Reader (Oxford: Blackwell, 2003); Stephen Castles and Mark J. Miller, The Age of Migration: International Population Movements in the Modern World, $3^{\text {rd }}$ ed. (New York and London: Guildford Press, 2003); Nicholas Van Hear, New Diasporas: The Mass Exodus, Dispersal and Regrouping of Migrant Communities (London: UCL Press, 1998).

3. Jose Itzigsohn and Silvia Giorguli Saucedo, "Immigrant Incorporation Transnationalism," International Migration Review 36, no. 3 (2002): 766-99.

4. Thomas Faist, The Volume and Dynamics of International Migration and Transnational Social Spaces (Oxford: Oxford University Press, 2000), 196.

5. Jenny Robinson, David Turton, Giles Mohan, and Helen Yanacopulos, Development and Displacement (Oxford: Oxford University Press / Milton Keynes: Open University Press, 2002), 4.

6. United Nations, Convention relating to the Status of Refugees, Article 1 A, Paragraph 2.

7. Benedict Anderson, Imagined Communities: Reflections on the Origin and Spread of Nationalism, rev. and extended ed. (1991; repr. London and New York: Verso, 1992), 163-64.

8. Eva Østergaard-Nielsen, International Migration and Sending Countries: Perceptions, Policies and Transnational Relations (Basingstoke, NH, and New York: Palgrave Macmillan, 2003); Poul Engberg-Pederson, Ninna Nyberg-Sorenson, and Nicholas Van Hear, The Migration-Development Nexus: Evidence and Policy Options (Geneva: International Organization for Migration, 2002).

9. Soumitra De, Nationalism and Separatism in Bengal: A Study of India's Partition (New Delhi: Har-Anand Publications, 1992), 15.

10. William van Schendel, "Working through Partition: Making a Living in the Bengal Borderlands," in Work and Social Change in Asia: Essays in Honour of Jan Bremen, ed. Arvind N. Das and Marcel van der Linden (New Delhi: Manohar, 2003), 54.

11. Jhumpa Lahiri, "When Mr. Pirzada Came to Dine" in Interpreter of Maladies: Stories of Bengal, Boston and Beyond (London: Harper-Collins, 1999), 25-26.
12. Sumit Sarkar, "Indian Democracy: The Historical Inheritance," in The Success of India's Democracy, ed. Atul Kohli (Cambridge: Cambridge University Press, 2001), 23-46.

13. David Washbrook, "The Rhetoric of Democracy and Development in Late Colonial India," in Nationalism, Democracy and Development: State and Politics in India, ed. Sugata Bose and Ayesha Jalal (Delhi: Oxford University Press, 1997), 36-49.

14. Ranajit Guha, Dominance without Hegemony: History and Power in Colonial India (Cambridge, MA: Harvard University Press, 1997).

15. Gyanendra Pandy, "The Prose of Otherness," in Subaltern Studies VIII: Essays in Honour of Ranajit Guha, ed. David Arnold and David Hardiman (Delhi: 1994), 194.

16. Amrita Kumar and Prashun Bhaumik, eds., Lest We Forget: Gujarat 2002 (New Delhi: World Report, 2002).

17. A.J. Kamra, The Prolonged Partition and Its Pogroms: Testimonies on Violence against Hindus in East Bengal 1946-64 (New Delhi: Voice of India, 2000).

18. Van Schendel, 55.

19. Suvir Kaul, ed., The Partitions of Memory: The Afterlife of the Division of India (Bloomington, IN: Permanent Black, 2001).

20. Vinod Kumar Saxena, ed., The Partition of Bengal (1905-1911): Select Documents (Delhi: Kanishka Publishing House, 1987).

21. Joya Chatterji, Bengal Divided: Hindu Communalism and Partition, 1932-1947 (Cambridge: Cambridge University Press, 1994).

22. Kanti B. Pakrasi, The Uprooted: A Sociological Study of the Refugees of West Bengal, India (Calcutta: Temple Press, 1971).

23. Nilanjana Chatterjee, "Interrogating Victimhood: East Bengali Refugees Narratives of Communal Violence," $<$ http:www.pstc.brown.edu/Chatterjee.PDF $>$ (accessed September 27, 2004).

24. Sandip Bandopadhyay, "Millions Seeking Refuge: The Refugee Question in West Bengal: 1971,” in Refugees in West Bengal: Institutional Practices and Contested Identities, ed. Pradip Kumar Bose (Calcutta: Mahanirban Calcutta Research Group, 2000), 33-38.

25. Prafulla K. Chakrabarty, The Marginal Men: The Refugees and the Left Political Syndrome in West Bengal (Calcutta: Naya Udyog, 1999), 280-90.

26. See Urvashi Butalia, The Other Side of Silence: Voices from the Partition of India (New Delhi: Viking, 1998); Veena Das, Mirrors of Violence: Communities, Riots and Survivors in South Asia (Delhi: Oxford University Press, 1990); Ritu Menon and Kamla Bhasin, Borders and Boundaries: Women in India's Partition (New Brunswick, NJ: Rutgers University Press, 1998).

27. John Broomfield, Elite Conflict in a Plural Society: TwentiethCentury Bengal (Berkeley: University of California Press, 1968), 5.

28. Gordon Johnson, "Partition, Agitation and Congress: Bengal 1904-1908,” Modern Asian Studies 7, no. 3 (1977): 534-35.

29. Chatterji, 3-13. 
30. John McGuire, The Making of a Colonial Mind: A Quantitative Study of the Bhadralok in Calcutta, 1857-1885 (Canberra: Australian National University, 1983).

31. Nilanjana Chatterjee, "East Bengal Refugees: A Lesson in Survival," in Calcutta: The Living City, ed. Sukanta Chaudhuri (Calcutta: Oxford University Press, 1990).

32. S.P. Chatterjee, The Partition of Bengal: A Geographical Study with Maps and Diagrams (Calcutta: EKA Press, 1947).

33. Joya Chatterji, "Right or Charity? The Debate over Relief and Rehabilitation in West Bengal, 1947-1950," in S. Kaul, The Partitions of Memory, 74-110.

34. Van Schendel, 61-77.

35. Sarbani Sen, "The Legal Regime for Refugee Relief and Rehabilitation in West Bengal, 1946-1958," in Bose, Refugees in West Bengal, 49-64.

36. Government of West Bengal, Annual Report of the Department of Rehabilitation, 1965-66 (New Delhi: Department of Rehabilitation, Government of West Bengal, 1967), 107.

37. Government of West Bengal, Manual of Refugee Relief and Rehabilitation (Calcutta: Government of West Bengal, 2001), 1.

38. Tai Yong Tan and Gyanesh Kudaisya, The Aftermath of Partition in South Asia (New York: Routledge, 2000).

39. Sabyasachi Basu-Roy Chowdhury, "Exiled to the Andamans: The Refugees from East Pakistan," in Bose, Refugees in West Bengal, 130-141.

40. Alok Ghosh, "Bengali Refugees at Dandakrayna: A Tragedy of Rehabilitation," in Bose, Refugees in West Bengal, 106-29.

41. Ibid., 117.

42. Manas Ray, "Growing Up Refugee: On Memory and Locality," History Workshop Journal 53 2002): 149-79.
43. Rachel Waber, "Re(Creating) the Home: Women's Role in the Development of Refugee Colonies in South Calcutta," in The Trauma and the Triumph: Gender and Partition in Eastern India, ed. Jasodhara Bagchi and Subhoranjan Dasgupta (Kolkata: Stree, 2003).

44. Arun Deb, "The UCRC: Its Role in Establishing the Rights of Refugee Squatters in Calcutta," in Bose, Refugees in West Bengal, 65-79.

45. Samir Kumar Das, "Refugee Crisis: Responses of the Government of West Bengal," in Bose, Refugees in West Bengal, 7-31.

46. Kolkata Metropolitan Development Authority, "Refugee Colony Development," <http://www.cmdaonline.com/ refcoldev.htm> (accessed November 28, 2004).

47. Interview with Promoter, Bengal Silver Springs (Bengal Ahluwalia Projects), Kolkata, April 27, 2004; Interview with Promoter, South City Projects, Kolkata, May 5, 2004; Interview with Promoter, Vedic Village Projects, Kolkata, May 12, 2004.

48. Interview with Community Organizer, People United for Better Living in Calcutta, Kolkata, May 16, 2004.

49. Hironmoy Bandyopadhyay, Udbastu (Calcutta: Sahitya Samsad, 1970).

Pablo S. Bose is a doctoral candidate in the Faculty of Environmental Studies and a Research Associate at the Centre for Refugee Studies, York University. His research looks at the involvement of diasporic South Asian-Canadian communities in dynamics of economic development and population displacement in India. 